HORTSCIENCE 25(11):1401-1402. 1990.

\title{
Nutritional Studies of Christmas Bell
}

\author{
G.P. Lamont ${ }^{1}$ \\ New South Wales Agriculture and Fisheries, Gosford, NSW 2250 \\ Australia \\ G.C. Cresswell \\ New South Wales Agriculture and Fisheries, BCRI Rydalmere, NSW \\ 2116 Australia
}

\section{G.J. Griffith}

New South Wales Agriculture and Fisheries, Gosford, NSW 2250

Australia

Additional index words. fertilizer, liliaceae, contractile roots, vegetative growth,
Blandfordia grandiflora

\begin{abstract}
Eighteen-month-old seedlings of Christmas Bell (Blandfordia grandiflora Sm.) in 800-ml containers were top dressed with 8- to 9-month Osmocote controlled-release fertilizer $18 \mathrm{~N}-2.6 \mathrm{P}-10 \mathrm{~K}$ at $0,0.625,1.25,2.5,5.0$, or $10 \mathrm{~kg} \cdot \mathrm{m}^{-3}$. Other plants were fertilized once or twice weekly with a complete liquid fertilizer supplying $100 \mathrm{mg}$ N/ liter based on an $N$ : $K$ ratio of either 1:0.6 or 1:1.5. The former ratio was the same as the Osmocote while the latter was the $N$ : K ratio in tops of healthy wild-growing plants of $B$. grandiflora. The highest fresh weights occurred at the Osmocote rate of 5 $\mathrm{kg} \cdot \mathrm{m}^{-3}$ and with the once-weekly liquid feed of $1 \mathrm{~N}: 1.5 \mathrm{~K}$ ratio. Plants fertilized with low rates of Osmocote were pale green but had extensive root systems that were white and predominantly fibrous. As the rate of Osmocote was increased, plants became greener and produced smaller root systems in which fleshy storage organs were predominant over fibrous roots.
\end{abstract}

Blandifordia is a small genus of the family Liliaceae endemic to the east coast of Australia. These tufted perennial herbs have a fibrous root system that forms a fleshy corm in mature plants. They are often widespread in well-drained acid heaths that are subject to periodic inundation. Blandfordias are slowgrowing, and take 3 years from seed before the first inflorescence is produced (Elliott and Jones, 1982).

The inflorescence comprises three to 18 tubular flowers or bells borne on an erect stem. Most commonly the bells are red with yellow tips, but pure red and pure yellow forms also exist. The main flowering period for Christmas bells in Australia is October

Received for publication 8 Nov. 1989. Appreciation is extended to B. Williams for technical support and L. Spohr for statistical analyses. Reference to trade products is only for purposes of publication and does not imply approval or recommendation of the product to the exclusion of others that may be suitable. The cost of publishing this paper was defrayed in part by the payment of page charges. Under postal regulations, this paper therefore must be hereby marked advertisement solely to indicate this fact.

'Present address: Leo Lynch and Sons, Warehouse H. Unit 16, Flemington Markets, 2129 Sydney, Australia. to January, hence their common name. Christmas bells may offer significant potential as a cut flower but there is limited commercial experience in their cultivation (Lament, 1988). We now report on the response of Blandfordia grandiflora to both controlled-release and liquid fertilizer.

In Aug. 1988, 18-month-old root-washed seedlings of $B$. grandiflora were planted into a potting medium of $50 \%$ peat moss and $50 \%$ river sand in $75-\mathrm{mm}$ pots of $800-\mathrm{ml}$ volume. The potting mix was amended with 1 lime : 1 dolomite (v/v) to adjust the $\mathrm{pH}$ to 5.0 , which is within the optimum range $(\mathrm{pH} 4$ to 6) for Christmas bells (unpublished data).

Ten replicate plants were graded by weight and allocated to each of the following treatments: 1) Osmocote 8- to 9-month controlled-release fertilizer $18 \mathrm{~N}-2.6 \mathrm{P}-10 \mathrm{~K}$ (Sierra Chemical, Milpitas, Calif.) applied to the soil surface at $0,0.625,1.25,2.5$, 5.0 , and $10 \mathrm{~kg} \cdot \mathrm{m}^{-3}(0,0.5,1.0,2.0,4.0$, and $8.0 \mathrm{~g} / \mathrm{pot}) ; 2$ ) liquid formula $A$ with a ratio of $1 \mathrm{~N}: 0.6 \mathrm{~K}$; and 3 ) liquid formula $\mathrm{B}$ with a ratio of $1 \mathrm{~N}: 1.5 \mathrm{~K}$. Formula A was the same $\mathrm{N}$ : K ratio as the Osmocote and $\mathrm{B}$ was the $\mathrm{N}: \mathrm{K}$ ratio observed in leaf tissue of healthy wild growing plants of $B$. grandiflora. The different $\mathrm{N}: \mathrm{K}$ ratios were achieved by varying the concentration of $\mathrm{K}$ 
Table 1. Effect of fertilizer treatment on plant fresh weight and shoot width and on the $\mathrm{pH}$ and electrical conductivity (EC) of the growing medium after 6 months.

\begin{tabular}{|c|c|c|c|c|c|}
\hline Fertilizer & $\begin{array}{l}\text { Application } \\
\left(\mathrm{kg} \cdot \mathrm{m}^{-3} \text { or }\right. \\
\text { frequency) }\end{array}$ & $\begin{array}{l}\text { Fresh } w^{z} \\
\text { (g) }\end{array}$ & $\begin{array}{l}\text { Shoot } \\
\text { width } \\
\text { (mm) }\end{array}$ & $\mathrm{pH}$ & $\begin{array}{c}\mathrm{EC} \\
\left(\mathrm{dS} \cdot \mathrm{m}^{-2}\right) \\
\end{array}$ \\
\hline Osmocote & $\begin{array}{l}0 \\
0.625 \\
1.25 \\
2.5 \\
5.0 \\
10\end{array}$ & $\begin{array}{l}32.5 \mathrm{c} \\
34.6 \mathrm{c} \\
36.8 \mathrm{bc} \\
35.9 \mathrm{bc} \\
51.2 \mathrm{a} \\
36.5 \mathrm{bc}\end{array}$ & $\begin{array}{l}11.7 \mathrm{~d} \\
14.1 \mathrm{~d} \\
14.5 \mathrm{~d} \\
18.4 \mathrm{c} \\
22.5 \mathrm{a} \\
19.6 \mathrm{bc}\end{array}$ & $\begin{array}{l}6.0 \mathrm{abc} \\
6.0 \mathrm{abc} \\
5.8 \mathrm{bc} \\
5.6 \mathrm{c} \\
4.9 \mathrm{~d} \\
3.7 \mathrm{e}\end{array}$ & $\begin{array}{l}0.36 \mathrm{f} \\
0.40 \mathrm{ef} \\
0.43 \mathrm{def} \\
0.76 \mathrm{c} \\
1.33 \mathrm{~b} \\
2.23 \mathrm{a}\end{array}$ \\
\hline \multicolumn{6}{|l|}{ Solution A } \\
\hline $1 \mathrm{~N}: 0.6 \mathrm{~K}$ & $\begin{array}{l}\text { Once weekly } \\
\text { Twice weekly }\end{array}$ & $\begin{array}{l}35.8 \mathrm{c} \\
31.9 \mathrm{c}\end{array}$ & $\begin{array}{l}17.2 \mathrm{c} \\
17.9 \mathrm{c}\end{array}$ & $\begin{array}{l}6.3 \mathrm{a} \\
6.4 \mathrm{a} .\end{array}$ & $\begin{array}{l}0.59 \mathrm{cde} \\
0.60 \mathrm{~cd}\end{array}$ \\
\hline Solution B & & & & & \\
\hline $\begin{array}{l}1 \mathrm{~N}: 1.5 \mathrm{~K} \\
\text { LSD } 5 \%\end{array}$ & $\begin{array}{l}\text { Once weekly } \\
\text { Twice weekly }\end{array}$ & $\begin{array}{c}45.3 \mathrm{ab} \\
34.2 \mathrm{c} \\
9.43\end{array}$ & $\begin{array}{c}19.5 b c \\
21.5 a b \\
2.8\end{array}$ & $\begin{array}{l}6.3 \mathrm{a} \\
6.1 \mathrm{ab} \\
0.39\end{array}$ & $\begin{array}{l}0.69 c \\
0.74 c \\
0.19\end{array}$ \\
\hline
\end{tabular}

${ }^{2}$ Lower case letters indicate Duncan's separations between means at $P=0.05$.

(55 to $150 \mathrm{mg} \cdot$ liter $^{-1}$ ) in a base nutrient solution containing (mg.liter $\left.{ }^{-1}\right) 100 \mathrm{~N}\left(3 \% \mathrm{NH}_{4}^{-}\right.$ $\mathrm{N}), 15 \mathrm{P}, 161 \mathrm{Ca}, 25 \mathrm{Mg}$, and $2 \mathrm{Fe}(\mathrm{FE}-$ EDTA). Solutions A and B were applied once or twice weekly. All 10 treatments received an application of Librel BMX micronutrient mix (Allied Colloids, Wyong, Australia) once a month.

Plants were arranged in a randomized complete-block design in an unheated greenhouse (temperature range 8 to $30 \mathrm{C}$ ) at Gosford, New South Wales, with natural daylength and $20 \%$ shading. Plants were handwatered when necessary and given $20 \%$ excess water once a week to minimize salt buildup in the mix.

After 3 months, leaf number, leaf length, and shoot width at the base of each plant, measured by calliper, were recorded. After 6 months, the $\mathrm{pH}$ and electrical conductivity (EC) of the mix in each pot was measured using the pour-through technique of Yeager et al. (1983). Shoot width was again measured before each plant was root-washed and weighed. Because these 2-year-old plants were required for other experimental use, the root and shoot fractions could not be determined. Treatment effects on all measured variables were tested using analyses of variance. A regression model was used to describe the response of final weight to increasing rates of Osmocote.

After 3 months, there was a significant treatment effect on shoot width but not on leaf number or leaf length (data not presented). After 6 months, the linear relation between shoot width and final weight was poor $\left(r^{2}=0.38\right)$. This was probably due to treatment effects on root : shoot ratios. These are described in detail below. Leaf number, leaf length, and shoot width are therefore of limited value as nondestructive measures of vegetative growth of Blandfordia.

Several weeks after the commencement of the trial, the oldest leaves of plants receiving $10 \mathrm{~kg}$ Osmocote $/ \mathrm{m}^{3}$ developed necrotic tips. Some older leaves eventually became completely necrotic and one plant from this treatment died. The roots of plants receiving 10 $\mathrm{kg}$ Osmocote $/ \mathrm{m}^{3}$ were brown and stunted, with many dead root tips. Similar leaf symp- toms were seen in both twice-weekly liquid feed treatments after $\approx 4$ months. Plants receiving Osmocote at 0 and $0.625 \mathrm{~kg} \cdot \mathrm{m}^{-3}$ were pale green or yellow and had some reddening around the margins of older leaves. In these treatments, plant roots were white, extensive, and predominantly fibrous. With increasing rates of Osmocote, plants were greener and had less-bulky root systems in which fleshy storage organs were predominant over fibrous roots. The roots of plants receiving liquid feed once a week were white with roughly equal amounts of fibrous and storage roots. Over the 6-month experimental period, shoots in all treatments were drawn down an average $2 \mathrm{~cm}$ in the pot by the contractile roots.

The tendency of Christmas bells to produce fibrous roots instead of storage roots at low fertility may improve the plant's ability to obtain nutrients in short supply by increasing the surface area of roots available for nutrient uptake and for myccorhizal infection (Bowen, 1981).

The response in final fresh weight to Osmocote was not adequately described by a linear $\left(r^{2}=0.03\right)$ or a quadratic model $\left(r^{2}\right.$ $=0.12$ ) because of the variation in root : shoot ratios. However, the $5 \mathrm{~kg} \cdot \mathrm{m}^{-3}$ rate gave a significantly higher fresh weight than other rates of Osmocote (Table 1). This is double the $2.5 \mathrm{~kg} \cdot \mathrm{m}^{-3}$ optimum rate of Osmocote recommended for Christmas bells by Dunston (1982). However, a reanalysis of his data shows the optimum rate to be $3.3 \mathrm{~kg} \cdot \mathrm{m}^{-3}$. Liquid fertilizer B applied once a week produced the heaviest plants of the liquid treatments, giving a comparable growth response to the best Osmocote rate.

The range in nutrient supply examined in the liquid feed treatments was too narrow to establish an optimum rate; consequently, the relative effectiveness of controlled-release and liquid feed programs could not be properly assessed. However, at equivalent rates of $\mathrm{N}$ supply (Osmocote rates of 1.25 and 2.5 $\mathrm{kg} \cdot \mathrm{m}^{-3}$ about correspond to the once- and twice-weekly liquid applications) no difference in growth was noted between Osmocote and liquid feeding. Increasing the frequency of liquid feeding from once to twice a week did not improve the growth of plants receiving solution A and caused root injury and reduced the growth of plants receiving solution B. This injury was possibly a response to excess salinity between each fertigation and the next watering. Similar root injury and poor growth occurred in the $10 \mathrm{~kg}$ Osmocote $/ \mathrm{m}^{3}$ treatment where the EC was 2.23 $\mathrm{dS} \cdot \mathrm{m}^{-1}$. Our observations suggest that an EC of $2 \mathrm{dS} \cdot \mathrm{m}^{-1}$, the approximate conductivity of the two liquid feed formulations, is excessive for Christmas bells.

Of the liquid feed treatments, only formula B applied once a week gave a significant increase in fresh weight over the control (0 Osmocote). This formulation had a ratio of $1 \mathrm{~N}: 1.5 \mathrm{~K}$, which is the average ratio of $\mathrm{N}$ and Kin tops of healthy plants collected in the wild. As $\mathrm{N}$ was supplied at 100 $\mathrm{mg} \cdot \mathrm{liter}^{-1}$ in both liquid feed formulations, growth differences between the two treatments were due to the availability of $\mathrm{K}$.

The $\mathrm{pH}$ of the media leachate determined after 6 months of growth decreased linearly with increasing rates of Osmocote. However, only at the highest rate of $10 \mathrm{~kg} \cdot \mathrm{m}^{-3}$ was the $\mathrm{pH}$ (3.7) considered too low for growing Christmas bells. This acidifying effect has been noted previously for Osmocote (Lament et al., 1988) and is presumably caused by leaching of $\mathrm{NO}_{3}-\mathrm{N}$ from the mix. Fertilizer uptake efficiencies of $<5 \%$ have been recorded for similar controlled-release products (S. Leake, personal communication). From plant analysis data, fertilizer application records, and final fresh weights, we estimate the $\mathrm{N}$ uptake efficiencies in this trial to range from $10 \%$ to $60 \%$.

Christmas bells were found to respond to fertilizer amendment and to tolerate quite high fertilizer rates. Best growth was achieved with 8- to 9-month Osmocote $18 \mathrm{~N}-2.6 \mathrm{P}-10 \mathrm{~K}$ at $5 \mathrm{~kg} \cdot \mathrm{m}^{-3}$ or with formula B once a week. A further improvement in growth may be achieved using a controlled-release fertilizer with a ratio of $1 \mathrm{~N}: 1.5 \mathrm{~K}$.

\section{Literature Cited}

Bowen, G.D. 1981. Coping with low nutrients, p. 33-64. In: J.S. Pate and A.J. McComb (eds.). The biology of Australian plants. University of Western Australia Press, Nedlands, Western Australia.

Dunstan, P.A. 1982. Studies on Christmas Bell (Blandfordia species) as a nursery and cut flower crop. Postgraduate diploma thesis in Horticulture, University of Sydney, Australia.

Elliott, W.R. and D.L. Jones. 1982. Encyclopaedia of Australian plants suitable for cultivation. vol 2. Lothian Publ. Co. Melbourne. p. 325326.

Lament, G.P. 1988. Native plants as cut flowers. Agfact H9.1.2. NSW Agr. \& Fisheries.

Lament, G.P., G.C. Cresswell, and L.J. Spohr, 1988. Response of Kentia Palm (Howea forsterana) to controlled-release fertilizer. Scientia Hort. 36:293-302.

Yeager, T.H., R.D. Wright, and S.J. Donohue. 1983. Comparison of pour-through and saturated pine bark extract on $\mathrm{N}, \mathrm{P}, \mathrm{K}$, and $\mathrm{pH}$ levels. J. Amer. Soc. Hort. Sci. 108:112-114. 